\section{Antiaris toxicaria (Moraceae) - a new distribution record to the Eastern Ghats}

\section{K. Ravikumar ${ }^{1} \&$ R. Vijaya Sankar ${ }^{2}$}

1,2 Bio-Cultural Repository of Indian Medicinal Plants, Foundation for Revitalisation of Local Health Traditions (FRLHT), \# 74/2, Jarakabande Kaval, Post Attur, via Yelahanka, Bangalore, Karnataka 560064, India.

Email: ${ }^{1}$ k.ravikumar@frlht.org

\section{Introduction}

Herbarium collections were made of a lofty tree from two different locations in the Eastern Ghats during the expedition trips primarily intended for medicinal plants' herbarium. The first collection was from Talakona forests in SeshachalamPalkonda hill range, Andhra Pradesh and the second collection was from Pachchaimalais in Tamil Nadu. The specimens were later identified as Antiaris toxicaria (Pers.) Lesch., belonging to the family Moraceae. In India, this paleotropical species is so far known only from the Western Ghats and Andaman Islands. This is the first report for the Eastern Ghats providing up to date nomenclature, brief description and some notes on its distribution.

Antiaris toxicaria (Pers.) Lesch. in Ann. Mus. Natl. Hist. Nat. 16: 478. t. 22. 1810 ; Hook.f., Fl. Brit. India 5: 537. 1888; T.Cooke, Fl. Pres. Bombay 2: 656(3:156). 1907; C.E.C.Fisch., Fl. Pres. Madras 3: 1367(957). 1928; Corner in Dassan. \& Fosb., Rev. Handb. Fl. Ceylon 3: 288. 1981; Saldanha, Fl. Karnataka 1: 109. 1984; K.M. Matthew, Ill. Fl. Palni hills t. 665. 1996; Sasidharan, Biodiv. Doc. Kerala 6: Fl. Pl. 437. 2004 Ipo toxicaria Pers., Syn. Pl. 2: 566. 1807. Antiaris innoxia Blume in Rumphia 1: 172, t. 54. 1835. Lepurandra saccidora Nimmo in Graham, Cat. Pl. Bombay 193. 1839. Antiaris saccidora (Nimmo)

Date of online publication 26 January 2009 ISSN $0974-7907$ (online) | 0974-7893 (print)

Editor: J.L. Ellis

\section{Manuscript details:}

Manuscript \# 01830; Received 28 July 2007; Final revised received 02 December 2008; Finally accepted 04 December 2008

Citation: Ravikumar, K. \& R.V. Sankar (2009). Antiaris toxicaria (Moraceae) a new distributional record to the Eastern Ghats. Journal of Threatened Taxa 1(1): 58-59.

Copyright: (C) K. Ravikumar \& R. Vijaya Sankar 2009. Creative Commons Attribution 3.0 Unported license. JoTT allows unrestricted use of this article in any medium for non-profit purposes, reproduction and distribution by providing adequate credit to the authors and the source of publication.

Acknowledgements: The authors are thankful to Shri D.K. Ved, Director, FRLHT, Bangalore for facility and encouragement; authorities of Forest Department of Andhra Pradesh and Tamil Nadu states for permission, guidance and facilities during field survey; Dr. D. Narasimhan, Department of Botany, Madras Christian College, Chennai for comments on the manuscript; Mr. Rathnakumar Department of Botany, Presidency College, Chennai for help in field survey at Pachchaimalais and the Ministry of Environment and Forests, New Delhi for financial support under 'Center of Excellence' project.

OPEN ACGESS | FREE DOWNLOAD
Dalz. in Hooker's J. Bot. Kew Gard. Misc. 3: 232. 1851; Wight, Icon. Pl. Ind. Orient. t. 1958. 1853; Bedd., Fl. Sylv. S. India t. 307. 1873. (Moraceae).

Diagnosis: Deciduous, monoecious trees, 30-50m tall; trunk 2-4m in girth, buttressed. Branches horizontal; outer bark brownish-grey, smooth, lenticellate; inner fibrous; blaze greenish, turning yellowish; wood white, soft; latex milky, pale yellow, turning brown. Leaves distichous, oblong or ovateelliptic, $c .10 \times 7 \mathrm{~cm}$, scabrid becoming glabrous above, subcoriaceous, subcordate at base, subacuminate at apex, entire or denticulate along margins; lateral nerves 8-12 pairs; petioles c $5 \mathrm{~mm}$ long, velvety; stipules small, caducous. Inflorescence on new shoots; male heads discoid, $c .1 .5 \mathrm{~cm}$ across, subtended by confluent imbricate bracts; tepals 4, spathulate; stamens 4-8; female flowers minute, solitary in an involucre of many confluent bracts; perianth absent; stylar arms 2, recurved. Drupes pyriform or subglobose, fleshy, reddish-brown, velvety, edible.

Flowering: January to March.

Materials examined: 29.i.2007, \pm 650m, Chittoor district, Talakona, Andhra Pradesh, coll. K. Ravikumar \& R. Vijaya Sankar, 105855 (Image 1). 31.iii.2007, \pm 900m, Tiruchirapalli district, Pachchaimalais, Kannimar Solai, Tamil Nadu, coll. K. Ravikumar 106135 (FRLH).

Remarks: In India, this species has so far been reported from the Western Ghats of Maharashtra, Karnataka, Kerala, Tamil Nadu and Andaman islands. The present collections record its presence for the first time in the Eastern Ghats as well as Andhra Pradesh.

Only a single tree was observed in Talakona forest in association with Anogeissus latifolia, Mallotus philippensis, Murraya paniculata and Sterculia urens. The proximity of this tree to a giant Entada pursaetha liane can be a threat to its survival in the future. Population of this species is much better in Pachchaimalais with 12 trees counted in Kannimar solai near Ramanathapuram where moist deciduous vegetation is present. This species is found growing along with Beilschmiedia bourdillonii, Celtis timorensis, Canarium strictum, Mangifera indica, Olea dioica, Schleichera oleosa, Streblus taxoides, Trema orientalis and stragglers like Morinda umbellata, Pisonia aculeata, Jasminum spp., etc. This patch of forest is also a home for a good population of Gnetum ula. It is suggested that this area be declared as a heritage site worth conserving.

None of the published literature (Pullaiah \& Moulali 1997; Pullaiah \& Rani 1999; Thammanna et al. 1994) on the plant diversity of Andhra Pradesh has reported the occurrence of this species. It is also not recorded by Matthew (1983) who explored the Pachchaimalais.

This species is culturally important from a historical perspective as the bark was used as cloth in ancient times. Botanically it is important that this tree from peninsular India is the tallest of this region. Fischer (1928) concurs with Beddome's statement: "The largest tree of South India, attaining 250ft. in height”.

\section{References}

Chithra, V. (1987). Family: Moraceae, p.250. In: Henry, A.N., G.R. Kumari 


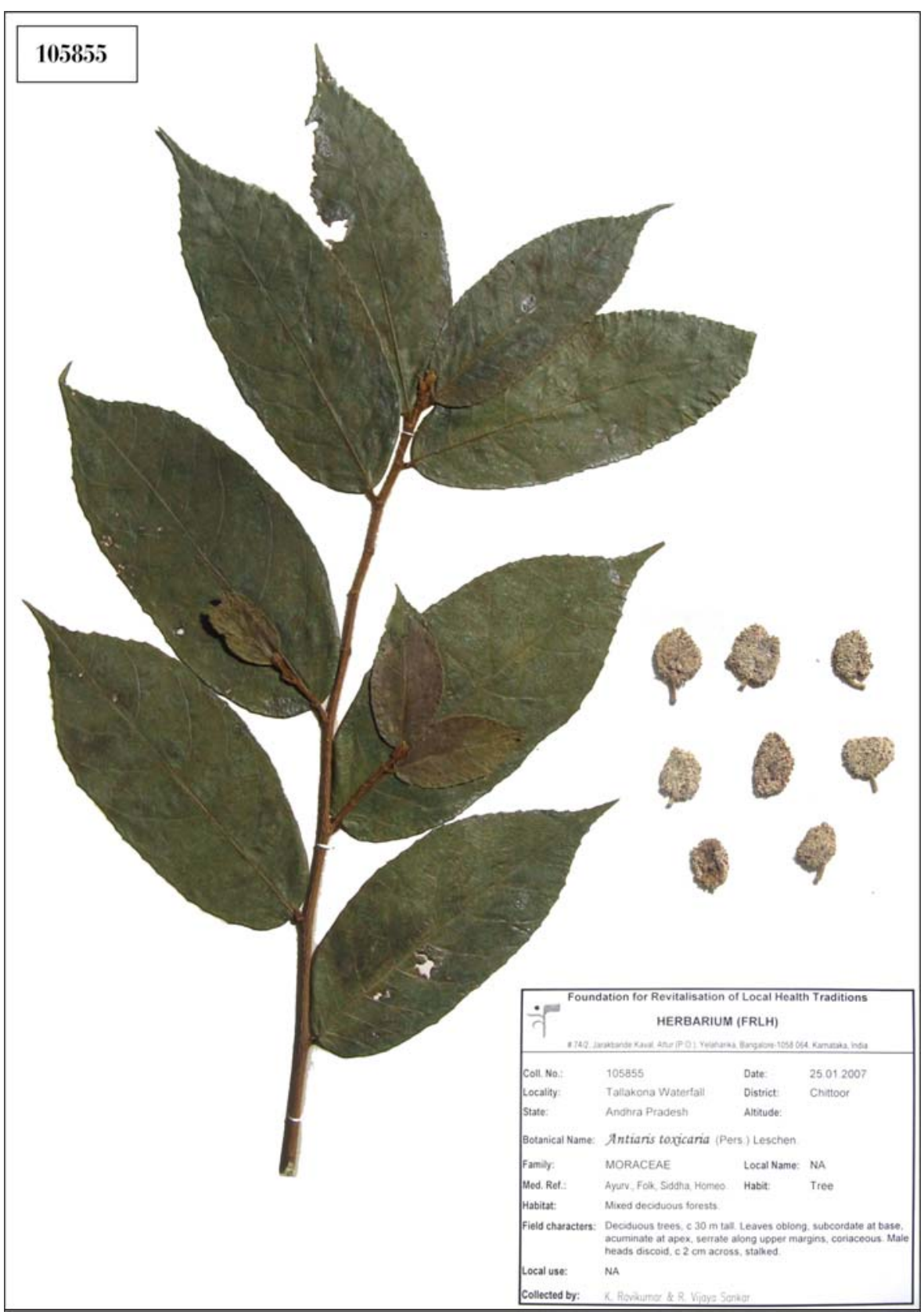

Image 1. Herbarium of Antiaris toxicaria from Eastern Ghats (FRLH 105855).
\& V. Chithra (eds.). Flora of Tamil Nadu, India. Series 1. Vol. 2. Botanical Survey of India, Coimbatore.

Dagar, J.C. \& N.T. Singh (1999). Plant Resources of the Andaman E Nicobar Islands. Vol. 2. Bishen Singh Mahendra Pal Singh, Dehra Dun, 645pp.

Fischer, C.E.C. (1928). Family CXXXVIII: Moraceae, pp.1367-68. In: Gamble, J.S. (ed.). Flora of the Presidency of Madras. Vol. 3. Adlard \& Son Limited, London.

Lakshminarasimhan, P. \& P. Venkanna (2001). Family: Moraceae, p.928. In: Singh, N.P., S. Karthikeyan \& P.V. Presanna (eds.). Flora of Maharashtra State (Dicotyledons). Vol 2. Botanical Survey of India, Calcutta.

Matthew, K.M. (1983). The Flora of the Tamilnadu Carnatic. Part 2. The Rapinat Herbarium, Tiruchirapalli, 1507-35pp.

Naithani, H.B., K.C. Sahni \& S.S.R. Bennet (1997). Forest Flora of Goa. International Book Distributors, Dehra Dun, 591pp.

Pullaiah, T. \& D.A. Moulali (1997). Flora of Andhra Pradesh (India). Scientific Publishers, Jodhpur, 894-906pp.

Pullaiah, T. \& S.S. Rani (1999). Trees of Andhra Pradesh, India. Regency Publishers, New Delhi, 420-437pp.

Saldanha, C. \& B.R. Ramesh (1984). Family: Moraceae, p.109. In: Saldanha, C. (ed.). Flora of Karnataka. Vol. 1. Oxford \& IBH Publishing Co., New Delhi.

Sasidharan, N. (2004). Biodiversity Documentation for Kerala-Part 6: Flowering Plants. Kerala Forest Research Institute, Peechi, Kerala, $437 \mathrm{pp}$.

Thammanna, K., N. Rao \& K. Madhavachetty (1994). Angiospermic Wealth of Tirumala. TTD, Tirupathi.

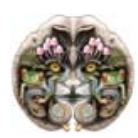

